\title{
Öğretmenlerde İş Stresi ve Mesleki Tükenmişliğin İş Tatmini ve Mesleki Duygusal Bağlılık Üzerindeki Etkisi
}

\section{Gökhan Karadirek1}

\section{Type/Tür:}

Research/Araştırma

Received/Geliş Tarihi:

February 20/20 Şubat 2020

Accepted/Kabul Tarihi:

November 2/2 Kasim 2020

Page numbers/Sayfa No: 101-122

Corresponding

Author/İletişimden Sorumlu

Yazar:

gokhankaradirek_28@hotmail.co $\underline{\mathrm{m}}$

\section{$\checkmark$ iThenticate}

This paper was checked for plagiarism using iThenticate during the preview process and before publication. / Bu çalışma ön inceleme sürecinde ve yayımlanmadan önce iThenticate yazılımı ile taranmıştır.

Copyright (C) 2017 by

Cumhuriyet University, Faculty of Education. All rights reserved.

\section{Öz}

Araştırmanın amacı, öğretmenlerin görevlerini yerine getirirken yaşadıkları iş stresi, mesleki tükenmişlik, iş tatmini ve mesleki duygusal bağlllık faktörleri arasındaki ilişkileri belirlemektir. Araştırma, nicel araştırma desenindedir. Araştırmanın hipotezlerini test etmek için kamu ve özel eğitim kurumlarından 550 öğretmenin oluşturduğu bir örneklem kullanılmıştır. Örneklemdekiler, basit tesadüfi örnekleme tekniğiyle belirlenmiştir. Araştırmanın verileri, anket yöntemiyle 11 Kasım-20 Aralık 2019 tarihleri arasında, öğretmenlerle yüz yüze görüşme yapılarak toplanmıştır. Veriler, uluslararası alanda tercih edilen bir yazılım aracılığıyla analiz edilmiştir. Verilerin güvenirliği Alfa ( $\alpha$ ) modeli (Cronbach Alfa Katsayısı) ile hesaplanmıştır. Faktörlerin belirlenmesinde özdeğer istatistiğinden yararlanılmış ve Varimax rotasyonu kullanılmıştır. Faktörlerin aralarındaki ilişkilerin derecesi Pearson Korelasyon katsayısı temel alınarak belirlenmiştir. Hipotezler, adım adım regresyon analizi metoduyla test edilmiştir. Araştırmanın sonucunda şu bulgulara ulaşılmıştır: İş tatminin ve mesleki duygusal bağlılığın iş stresi ve mesleki tükenmişlik boyutlarıyla (kişisel başarıda azalma, duyarsızlaşma, duygusal tükenmişlik) arasında anlamlı ve negatif bir ilişki bulunmaktadır. İş tatmini ile mesleki duygusal bağlllık arasında ise pozitif bir ilişki bulunmuştur. İş stresinin ve mesleki tükenmişlik boyutlarının iş tatmini üzerinde anlamlı ve negatif bir etkisi vardır. Mesleki duygusal bağlılık üzerinde iş tatmininin pozitif etkisi vardır. Duygusal tükenmişlik ve duyarsızlaşmanın ise mesleki duygusal bağlılık üzerinde olumsuz bir etkisinin olduğu sonucuna ulaşılmıştır. Diğer taraftan, iş stresinin ve kişisel başarıdaki azalmanın mesleki duygusal bağlılık üzerinde anlamlı bir etkisi bulunamamıştır. Dolayısıyla öğretmenlerin iş stresi ve mesleki tükenmişlik yaşamalarına neden olan temel faktörler belirlenmeli, bu faktörlerin tamamen ortadan kaldırılmasına yönelik çalışmalar yapılmalı ya da faktörlerin etkilerinin en aza indirilmesi sağlanmalıdır. Bu şekilde öğretmenlerin iş tatmini duygusunu ve mesleki duygusal bağlılı̆̆ını artırmak mümkündür.

Anahtar Kelimeler: İş stresi, mesleki tükenmişlik, iş tatmini, mesleki duygusal bağlllık, öğretmenlik

\section{Suggested APA Citation/Önerilen APA Atıf Biçimi:}

Karadirek, G. (2021). Öğretmenlerde iş stresi ve mesleki tükenmişliğin iş tatmini ve mesleki duygusal bağll1lk üzerindeki etkisi. Cumhuriyet International Journal of Education, 10(1), 101-122. http://dx.doi.org/10.30703/cije.692020

\footnotetext{
1 Öğr. Gör. Dr., Giresun Üniversitesi, Alucra Turan Bulutçu Meslek Yüksekokulu, Giresun/Türkiye Lecturer, PhD, Giresun University, Alucra Turan Bulutçu Vocational Education \& Training School, Giresun/Turkey e-mail: gokhankaradirek_28@hotmail.com ORCID ID: orcid.org/0000-0002-0804-9904
} 


\title{
The Effect of Job Stress and Occupational Burnout on Job Satisfaction and Occupational Affective Commitment in Teachers
}

\begin{abstract}
This paper aims to examine the relationships between the job stress, occupational burnout, job satisfaction and occupational affective commitment factors that teachers' experience while performing their duties. The research has a quantitative research pattern. A sample of 550 teachers from public and private schools was used to test the hypotheses of the research. The ones in the sample were determined by simple random sampling technique. The data of the research were collected through the survey method between 11 November and 20 December 2019 by face-to-face interviews with teachers. The reliability of the data was calculated with the Alpha (a) model (Cronbach Alpha Coefficient). Eigenvalue statistics were used to determine the factors and Varimax rotation was used. The degree of relationship between the factors was determined based on the Pearson Correlation coefficient. Hypotheses were tested by stepwise regression analysis method. As a result of the research, the following findings were reached: There is a significant and negative relationship between job satisfaction and occupational affective commitment and job stress and occupational burnout dimensions (decrease in personal accomplishment, depersonalization, emotional exhaustion). A positive relationship was found between job satisfaction and occupational affective commitment. A positive relationship was found between job satisfaction and occupational affective commitment. Job stress and occupational burnout dimensions have a significant and negative effect on job satisfaction. Job satisfaction has a positive effect on occupational affective commitment. It was concluded that emotional exhaustion and depersonalization have a negative effect on occupational affective commitment. On the other hand, there was no significant effect of job stress and decrease in personal accomplishment on occupational affective commitment. Therefore, the main factors that cause teachers to experience work stress and occupational burnout should be identified, eliminated or the effects of these factors should be minimized. In this way, it is possible to increase teachers' job satisfaction and occupational affective commitment.
\end{abstract}

Keywords: Job stress, occupational burnout, job satisfaction, occupational affective commitment, teaching

\section{Giriş}

Eğitim kurumları, ülkelerin sahip olduğu en büyük ve en önemli örgütlerdendir. Bu örgütün insan kaynağının çoğunluğunu, örgütün amacına doğrudan hizmet eden, uzmanlıkları farklı öğretmenler oluşturmaktadır. Öğretmenler, bir ülkenin gençlerinin geleceğine doğrudan katkı sağlayan ve etkisi olan temel örgüt üyeleridir. Öğretmenler, toplumun önemli ve değerli bireylerindendir. Bu sebeple geleceğin bilim insanlarının eğitilmesinde büyük paya sahip öğretmenlerin mesleklerinde yaşadıkları duyguları bilmek, mesleki bağlamda olumsuz duyguları var ise bunları ortadan kaldıracak adımlar atmak, olumlu duygularının devamlılı̆ını sağlamak hem öğretmenlerin yetiştirdiği öğrenciler hem de bu öğrencilerin görev alacağı örgütlerin verimliliği için önemlidir. Çünkü öğretmenlik mesleği, gün boyu özellikle genç bireylerle, öğrencilerle yakın ve sürekli iletişimin kurulduğu nadir ve özel bir görevdir. Ayrıca bu mesleği yerine getirenler, örgüt içinden ve dışından etkilenebilmektedir. Kısaca, mesleğin gereği ve özelliği, öğretmenlerde farklı duyguların, hislerin gelişmesine, yeni davranışların ortaya çıkmasına neden olabilmektedir. Örneğin, iş stresi, tükenmişlik (duyarsızlaşma, duygusal tükenmişlik, kişisel başarıda azalma), mesleki tatmin ve bağlllık, performans, örgütsel bağlllık ve 
vatandaşlık davranışı gibi duygular ve davranışlar bunlardan bazılarıdır. Dolayısıyla mesleki niteliğin, örgütsel ortamın ve örgüt dışındaki çevrenin çalışanların üzerinde yarattığ1 etkiyi belirlemek, sonuçlarını nedenleriyle birlikte ortaya koymak ve açıklamak, problemlere yönelik çözüm önerileri geliştirmek bilimsel araştırmanın bir gereğidir.

$\mathrm{Bu}$ çalışma, iş stresi, iş tatmini, mesleki tükenmişlik, mesleki duygusal bağlılık kavramları arasındaki ilişkileri öğretmenlik mesleği çerçevesinde ele almaktadır. Bu nedenle örneklemdekilerin yanıtları, iş stresi, iş tatmini, mesleki tükenmişlik ve mesleki duygusal bağlılık ölçekleriyle sınırlandırılmış veriler olup, öğretmenlerin meslekleriyle ilgili duygu ve düşüncelerini yansıtmaktadır.

\section{Kavramsal Çerçeve}

$\mathrm{Bu}$ araştırmanın temeli, iş stresi, mesleki tükenmişlik, iş tatmini ve mesleki duygusal bağl1lık kavramları üzerine kurulmuştur. Araştırma çerçevesinde bu kavramların ne anlama geldiği sırayla kısaca açıklanmaktadır.

İş stresi: Stres, bireyin yaşadığı ruhsal bir gerilimdir ve birçok çeşidi bulunmaktadır. Bunlardan biri iş stresidir. İş stresi, işle ilgili bazı faktörlerden oluşmaktadır. Bu faktörler; rol çatışması, rol belirsizliği, çalışanlardan çok sayıda görevi yerine getirmesini istemek ve bu görevler için yeterli kaynakların bulunmaması gibi aşırı görev yükü, işin tehlikeli olduğu duygusunu içeren, iş stresine neden olan, iş stresini harekete geçiren uyarıcılardır (Lambert vd., 2005: 33). İş stresi, örgütlerin tüm kademelerine (ast kademedekinden yöneticilere kadar) ve işe yeni alınmış personelin performansına, örgütsel verimliliğine etki edebilen hem ruhsal hem de fiziksel bir rahatsızlik duygusudur (Akova vd., 2015).

Mesleki Tükenmişlik: Tükenmişlik, duygusal tükenme ve bir sinizm sendromudur. Tükenmişlik, genellikle çalışan insanlar arasında görülmektedir (Maslach ve Jackson, 1981: 99) ve literatürde mesleki ya da iş tükenmişliği şeklinde kullanılmaktadır. Mesleki tükenmişlik, insanların mesleğinde çaba gösterme yeteneğindeki azalma, bir yorgunluk veya hayal kırıklığı durumudur (Griffin vd., 2010; Hurst ve Hurst, 1997). Maslach ve Jackson (1981), tükenmişliğin üç alt boyutunun olduğunu ileri sürmektedir. Bunlar, duygusal tükenmişlik, duyarsızlaşma ve kişisel başarıdır.

İş Tatmini: İş tatmini, çalışanların mesleğini ya da işini ne kadar çok sevdiğini gösteren (Spector, 1999) işle ilgili duygusal bir tepkidir. Bu duygusal tepki, umut edilen, beklenilen ve ihtiyaç duyulanın gerçek sonuçlarla kıyaslanmasının sonucunda ortaya çıkmaktadır (Griffin vd., 2010). İş tatmini, birinin iş deneyimlerinin değerlendirilmesinden kaynaklanan zevkli ve olumlu duygusal koşulların bir kombinasyonudur (Sharma ve Chalotra, 2017).

Mesleki Duygusal Bağlılık: Duygusal bağl1lık, örgütsel bağlılı̆̆ın temel boyutlarındandır (Meyer ve Allen, 1991). Duygusal bağlılık, genellikle bireyin örgüte sadakat göstermesi, çalışanın bulunduğu örgütle gurur duyması ve onun hedeflerini özümsemesi; örgütle kendisini içselleştirmesi, örgüte katılmaya ve örgüt uğruna kişisel çaba göstermeye istekli olmasıdır (Mowday vd., 1979). Meyer ve Allen (1993) çalışmasında örgütsel bağlılık boyutlarını açıklarken duygusal bağlılı̆̆ mesleki boyutta ele alan bir ölçek geliştirmiştir. Bu araştırmada, duygusal bağlılık, mesleki düzeyde ele alınarak öğretmenlik mesleğinin duygusal bağl1lı̆ğ1 incelenmiştir. Bu 
nedenle öğretmenlik mesleğinin yarattığı bağl1lık duygusu ön planda tutularak, mesleki duygusal bağlılığın; iş stresi, iş tatmini ve mesleki tükenmişlikle ilişkisinin daha anlamlı sonuçların ortaya konulmasını sağlayacağı varsayılmıştır.

\section{Teorik Altyapı ve Hipotezler}

İş stresi-iş tatmini ilişkisi. Bilimsel çalışmalar incelendiğinde, iş stresiyle iş tatmini arasındaki ilişkileri ortaya koymak için değişik meslek gruplarının örnek seçildiği görülmektedir. Cezaevi personeli üzerinde yapılan iki ayrı çalışmanın bulgularına göre, iş stresiyle iş tatmini arasında negatif yönlü bir ilişki vardır (Lambert vd., 2005; Griffin vd., 2010). Araştırma evreni olarak üniversitedeki araştırma görevlilerinin seçildiği başka bir çalışma, iş stresinin toplam iş tatmin üzerinde negatif yönlü doğrusal etkisinin olduğunu vurgulamaktadır (Bayar ve Öztürk, 2017). Beş yıldızlı otel işletmeleri çalışanlarının bir ankete verdikleri yanıtlarının analiz edilmesiyle de iş stresinin iş tatminiyle negatif ilişkisinin olduğu bulunmuştur (Akova vd., 2015). Mesleki stresle iş doyumu arasındaki ilişkiyi incelemek için kamu ve özel banka personelinden elde edilen veriler analiz edilmiş ve şu sonuca ulaşılmıştır: Mesleki stresle iş doyumu arasında negatif yönlü bir ilişki vardır (Güner vd., 2014). Tayvan'da farklı hastanelerden radyologların üzerinde bir araştırma yapılmıştır. Bu araştırmayla; iş stresi ile iş tatmini arasında negatif yönlü bir ilişkinin olduğu sonucuna varılmıştır (Lin vd., 2013). Algılanan stres, tükenmişlik ve iş tatmini arasındaki ilişkileri ortaya koyabilmek için okul rehberlerinden veriler toplanmıştır. $\mathrm{Bu}$ verilerin analizinden; iş tatminiyle iş stresi arasında negatif yönlü bir ilişkinin olduğu bulunmuştur (Mullen vd., 2018). Keşmir'de, çağrı merkezlerindeki çalışanlarının yaşadığı iş stresiyle iş tatmini arasında negatif yönlü bir ilişkinin olduğundan bahsedilmiştir (Sharma ve Chalotra, 2017). İş stresiyle iş tatmini arasındaki ilişkiyi açıklamak için polis memurları üzerinde de bir çalışma yapılmıştır. Çin'de polis memurları üzerinde yapılan bu çalışmaya göre; polislerin yaşadığ1 iş stresiyle iş tatmini arasında negatif ilişkili bulunmaktadır (Wang vd., 2014). Son zamanlardaki çalışmalardan elde edilen bulgular benzer sonuçlar vermektedir. Lambert ve diğerlerine (2018) göre polislerin yaşadığ 1 iş stresiyle mesleki iş tatmini arasında negatif ilişki bulunmaktadır (Lambert vd., 2018). İran'daki bir örgüt çalışanlarından elde edilen veriler analiz edildiğinde; mesleki stresin iş tatmini üzerinde doğrudan olumsuz etkisinin olduğu görülmüştür (Aghdasi vd., 2011). Türkiye'de öğretmenler üzerinde yapılan araştırmalarda da benzer bulgulara ulaşılmıştır. Örneğin, Turhan ve diğerlerine (2018) göre iş doyumu ile iş stresi arasında düşük düzeyde anlamlı ve negatif bir ilişki vardır. Günbayı ve Tokel (2012) de iş stres ile iş doyumu arasında yüksek düzeyde anlamlı ve ters yönlü bir ilişkinin olduğu sonucuna ulaşmıştır. İş doyumunun düşük olduğu durumlarda iş stresi yüksek, iş doyumunun yüksek olduğunda ise iş stresi düşüktür. Bu araştırma ayrıca, hizmet süresiyle iş doyumu arasında negatif ve orta düzeyde, görev yeri ile iş doyumu arasında pozitif ve düşük düzeyde ilişkinin olduğunu göstermiştir. Yine örneklemini öğretmenlerin oluşturduğu bir araştırmaya göre, algılanan stres mesleki doyumu negatif yönde etkilemektedir (Fırat, 2018). Yürür ve Keser (2010) işe bağlı gerginlik, iş tatmini ve duygusal tükenmişlik kavramları arasındaki ilişkiyi incelemek için lise ve ilköğretim öğretmenleri üzerinde bir araştırma yapılmıştır. Bu araştırmanın sonucunda, işe bağlı gerginliğin iş tatminini negatif yönde etkilediği ifade edilmiştir. 
Literatürdeki çalışmalardan hareketle öğretmenlerin mesleki görevlerini yerine getirirken yaşadığı iş stresiyle iş tatmini arasındaki ilişki için bu araştırmada şu varsayım önerilmektedir:

vardir.

Hipotez 1: Öğretmenlerin yaşadı̆̆ı iş stresinin iş tatmini üzerinde negatif etkisi

İş stresi-mesleki duygusal bağlılık ilişkisi. Literatürde, iş stresiyle mesleki duygusal bağlılık arasındaki ilişkiden ziyade genellikle iş stresiyle örgütsel bağlılık arasındaki ilişki araştırma konusu yapılmaktadır. Belli bir meslek grubu veya gruplarının iş stresiyle örgütsel bağl1lığı araştırılmış olması, örgütsel bağlılık kavramı kadar mesleki duygusal bağlılığı da ilgilendirmektedir. Meyer ve diğerleri (1993) örgütsel ve mesleki duygusal bağlılık kavramlarının aynı olmadığını gösteren iki ölçekle bunu ifade etmek istemiştir. Bu kavramlar arasındaki ilişkiyi araştıran çalışmaların genel olarak ortak tarafı; iş stresinin örgütsel ve mesleki duygusal bağlılıkla arasındaki ilişkinin negatif yönlü olduğudur. Lambert ve diğerleri (2005) ile Griffin ve diğerleri (2010) meslek grubu olarak aynı evrenden topladıkları verileri analiz ettiklerinde, benzer sonuçlara ulaşmıştır. İş stresiyle örgütsel bağlılık arasında negatif yönlü bir ilişki vardır (Lambert vd.,2005; Griffin vd., 2010). Çin'de, sağlık çalışanlarının örneklemini oluşturduğu bir çalışmadan varılan sonuç; iş stresiyle duygusal bağlılık arasında negatif yönlü bir ilişkinin olduğudur (Yang vd., 2017). Yine, Tayvan'da farklı hastanelerin radyologları üzerinde yapılan araştırmanın sonucu da iş stresi ile örgütsel bağlılık arasında anlamlı negatif bir ilişkinin olduğunu göstermiştir (Lin vd., 2013). Az sayıda olsa da bazı araştırmalarda doğrudan mesleki duygusal bağlılığın iş stresiyle ilişkisi açıklanmıştır. Polislerin yaşadığı iş stresinin üç boyutu, onların iş tatminini ve mesleki duygusal bağlılıklarını etkilemektedir (Kuo, 2015). Kuo'ya (2015) göre, iş stresinin duygusal bağlılığın açıklanmasına katkısı vardır. Başka bir araştırmaya göre de polislerin yaşadığı iş stresleriyle mesleki olarak duygusal bağlılıkları arasında negatif bir ilişki bulunmaktadır (Lambert vd., 2018). Araştırmanın evrenini ortaöğretim düzeyindeki okullarda görev yapan öğretmenlerin oluşturduğu çalışmanın bulgularında da örgütsel bağlılıkla iş stresi arasında düşük düzeyde anlamlı ve negatif bir ilişki tespit edilmiştir. Örgütsel bağlılığın duygusal ve normatif örgütsel bağlılık boyutlarının iş stresiyle negatif ilişkisinin olduğu görülmüştür (Turhan vd., 2018). Yukarıdaki bulgularda görüldüğü üzere, belli meslek grupları ele alınarak çalışanların iş stresiyle örgütsel duygusal ya da mesleki duygusal bağlılık arasındaki ilişkiler araştırılmış ve bu ilişkilerin negatif yönlü olduğu görülmüştür. Alan yazındaki bulgulardan hareketle, öğretmenlik mesleğindekilerin de yaşadıkları iş stresinin mesleki duygusal bağlılıkla arasındaki ilişkiye dair aşağıdaki varsayım ortaya atılmıştır:

Hipotez 2: Öğretmenlerin yaşadığı iş stresinin mesleki duygusal bağl1lık üzerinde negatif etkisi vardır.

Mesleki tükenmişlik- iş tatmin ilişkisi. Bir üniversitenin çalışanları üzerinde gerçekleştirilen araştırmaya göre, iş tükenmişliğiyle iş tatmini arasında ters yünlü, negatif ilişki vardır (Salehi ve Gholtash, 2011). Wang ve diğerlerine (2014) göre, duyarsızlaşma ve duygusal tükenmişlik, iş tatminini negatif bir şekilde etkilemektedir. Kişisel başarı ise iş tatminini pozitif bir şekilde etkilemektedir. İş tatminiyle tükenmişliğin üç boyutuyla; kişisel başarı duygusunun azalması, duygusal tükenmişlik ve duyarsızlaşma arasında düşük düzeyde negatif ilişki bulunmaktadır 
(Lambert vd., 2018). Algılanan stres, tükenmişlik ve iş tatmini arasındaki ilişkileri ortaya koyabilmek için okul rehberinden veriler toplanmıştır. Bu verilerin analizinden; iş tatminiyle tükenmişlik arasında istatistiki olarak anlamlı ve negatif yönlü bir ilişkinin olduğu bulunmuştur (Mullen vd., 2018). Griffin ve diğerlerine (2010) göre, mesleki tükenmişliğin boyutlarıyla; duyarsızlaşma, kişisel başarıda azalma ve duygusal tükenmişlikle iş tatmini arasında negatif yönlü bir ilişki vardır. Türkiye'de ilköğretim ve ortaöğretim okullarında görev yapan öğretmenlerin iş doyumuyla mesleki tükenmişlik duyguları arasındaki ilişki araştırılmış ve şu bulgulara ulaşılmıştır: iş doyumuyla mesleki tükenmişlik duygusu arasında negatif yönlü bir ilişkinin olduğu sonucuna ulaşılmıştır (Ertürk ve Keçecioğlu, 2012). Ertürk ve Keçecioğlu' na göre mesleğinden dolayı tükenmişlik yaşayan bir bireyin işinden mutlu olmasını beklemek çok mantıklı değildir. Çünkü, mesleki tükenmişlik işe karşı hissedilen bir memnuniyetsizlik fonksiyonudur. Bu nedenle mesleki tükenmişlikten dolayı iş doyumsuzluğunun yaşanması daha olasıdır. Tabi ki her iş doyumsuzluğunu mesleki tükenmişlikle ilişkilendirmek de doğru bir yaklaşım değildir. Alan yazında, mesleki tükenmişlik boyutlarının iş tatmini arasındaki genel ilişki sonuçları, öğretmenlik mesleğindekiler için de benzer ilişkileri yansımakta mıdır? Bu soruya yanıt bulabilmek için şu varsayımlar geliştirilmiştir: etkiler.

Hipotez 3a: Öğretmenlerin duyarsızlaşması, iş tatminini negatif bir şekilde

Hipotez 3b: Öğretmenlerin yaşadığı duygusal tükenmişlik, iş tatminini negatif bir şekilde etkiler.

Hipotez 3c: Öğretmenlerin kişisel başarılarındaki azalma, iş tatminini negatif bir şekilde etkiler.

Mesleki tükenmişlik-mesleki duygusal bağlılık ilişkisi. Griffin vd., (2010)'a göre, mesleki tükenmişliğin; duyarsızlaşma, kişisel başarıda azalma ve duygusal tükenmişlik boyutlarıyla örgütsel bağlılık arasında negatif yönlü bir ilişki vardır. Başka bir çalışmada, iş tükenmişliğinin örgütsel bağlılık üzerinde negatif etkisinin olduğu vurgulanmaktadır (Salehi ve Gholtash, 2011). Polis memurlarının duygusal bağlılığıyla tükenmişliğin; kişisel başarı duygusunun azalması, duygusal tükenmişlik ve duyarsızlaşma boyutu arasında negatif ilişki bulunmaktadır (Lambert vd., 2018). Duygusal bağlılığın duygusal tükenme, duyarsızlaşma ve başarı duygularında azalmayla negatif bir ilişkisi olduğunu göstermektedir (Garland vd., 2014). Evrenini İstanbul serbest muhasebeci mali müşavirler odaları üyelerinin oluşturduğu bir araştırmanın sonucu göstermiştir ki: Duygusal mesleki bağllikla duygusal tükenmişlik arasında negatif ilişki bulunmuştur. Ayrıca, tükenmişliğin duygusal tükenme boyutunun duygusal mesleki bağll1ık ile duygusal işten ayrılma niyeti arasındaki ilişkiye de kısmi aracılık etkisi vardır (Ciftcioglu, 2011).

Hipotez 4a: Öğretmenlerin duyarsızlaşması, mesleki duygusal bağlılığı negatif etkiler.

Hipotez 4b: Öğretmenlerin yaşadığı duygusal tükenmişlik, mesleki duygusal bağl1lı̆ı negatif etkiler.

Hipotez 4c: Öğretmenlerin kişisel başarılarındaki azalma, mesleki duygusal bağlılığı negatif etkiler. 
İş tatmini-mesleki duygusal bağlılık ilişkisi. İş tatminiyle örgütsel bağlılık arasında pozitif ilişki vardır (Salehi ve Gholtash, 2011). Griffin vd., (2010)'a göre, iş tatminiyle örgütsel bağlılık pozitif ilişkilidir. Duygusal bağlılık olumlu iş deneyimleri deneyimleriyle ilişkilidir. Mesleğe duygusal bağlılık, arzu edilen davranışlar veya davranışsal niyetlerle pozitif ilişkili iken, istenmeyen davranışlarla (örneğin, mesleği ve örgütü terk etme niyeti, devamsızlık ve ihmal) negatif ilişkilidir (Meyer vd., 1993). Öğretmenlerin iş doyumu ile duygusal bağlılıkları arasında pozitif ilişki vardır (Turhan vd., 2018). Güçlü ve Zaman (2011) alan dişından atanmış rehber öğretmenleri üzerinde yaptıkları araştırmanın sonucunda; rehber öğretmenlerinin iş doyum düzeyleriyle örgütsel bağlılıkları arasında anlamlı ve pozitif yönlü bir ilişkinin olduğunu ifade etmiştir. Hindistan'daki polis memurlarının duygusal bağlılıkla iş tatmini arasında pozitif ilişki vardır (Lambert vd., 2018). Polislerin işlerinden tatmin olması, duygusal bağlılı̆̆ pozitif bir şekilde etkilemektedir (Kuo, 2015). İş tatminiyle duygusal bağlılık arasında pozitif ilişki vardır (Irving vd., 1997). İş tatminiyle duygusal mesleki bağlılık arasında pozitif ilişki vardır (Salzmann vd., 2018). Pakistan'da özel ve kamu olmak üzere iki üniversitenin çalışanlarından veri toplanmış ve analiz edilmiştir. Bu analiz sonucunda, mesleki iş tatminiyle mesleki duygusal bağlılık arasında pozitif ilişkinin olduğu sonucuna ulaşılmıştır (Yousaf vd., 2013).

Hipotez 5: Ordu ilindeki öğretmenlerin mesleki duygusal bağlılığı üzerinde iş tatmininin pozitif etkisi vardir.

\section{Araştırmanın Amacı ve Önemi}

Araştırmanın amacı, öğretmenlerin görevlerini yerine getirirken yaşadıkları iş stresi, mesleki tükenmişlik, iş tatmini ve mesleki duygusal bağlılık faktörleri arasındaki ilişkileri belirlemektir.

İnsanlar meslek tercihi yaparken birtakım beklentiler içerisine girmektedir. Öğretmenlik de genellikle hem maddi hem de sosyal statü olarak beklentilerin karşılanabildiği mesleklerdendir. Toplumumuzda öğretmenlik, sayg1 duyulan, üniversiteye hazırlık döneminde çok sayıda öğrencilerin öğretmen olmayı hayal ettiği, istediği, beklentilerini karşılayacağına inandıkları bir meslektir. Hayaller ve beklentiler, gerçeğe dönüştüğünde çok büyük mutluluklar yaşanabilmektedir. Ancak, her zaman beklentilerin karşılanması mümkün olmayabilir. Bazen bireyler sosyal, ekonomik, duygusal, örgütsel düzeyde hayal kırıklığ1 yaşayabilir. Tüm olumlu ve olumsuz durumlar, öğretmenlerde bazı duyguların yaşanmasına, yeni davranışların ortaya çıkmasına ve sonuçlara neden olabilir. Özellikle değişen sosyal, ekonomik, mesleki ve örgütsel koşulların bazı mesleklerdeki tükenmişlik, iş stresi, mesleki bağlılık ve tatmin duygusunun belirleyicisi olabileceği bu araştırmanın alan yazınında ifade edilmiştir.

Alan yazından çıkarılan genel sonuç; iş stresi, mesleki tükenmişlik, iş tatmini ve mesleki veya duygusal bağlılık kavramları arasında anlamlı ilişkilerin olduğudur. Ancak, bağımlı ve bağımsız değişken arasındaki her anlamlı ilişkinin anlamlı bir etkiye neden olacağını söyleyemeyiz. Bu kapsamda, aşağıdaki sorulara öğretmenlerin düşüncelerinden yola çıkılarak cevap bulmak, değişkenler çerçevesinde önceki araştırmaların bulgularının genel geçerliliğinin sorgulanması bakımından bu araştırma için önemlidir. 
- $\quad$ Öğretmenlerin mesleğiyle ilgili algıladıkları stresin ve yaşadıkları mesleki tükenmişliğin mesleki duygusal bağlılık ve iş tatmini üzerinde bir etkisi var mıdır? Bir etki söz konusu ise bu etkinin yönü nedir ve iş tatmini ile mesleki duygusal bağl1lık üzerinde en güçlü anlamlı etkisi bulunana bağımsız değişken hangisi/hangileridir?

- Mesleki duygusal bağlılık üzerinde öğretmenlerin iş tatmin duygusunun anlamlı bir etkisi var mıdır? Var ise bu etkinin yönü ve gücü nedir?

\section{Yöntem}

Nicel araştırma yöntemiyle verilerin elde edildiği bu çalışmanın amacı ve önemi, veri toplama aracı ve süreci, evren ve örneklem, verilerin analizi ve bulgularla ilgili bilgiler sırasıyla aşağıda açıklanmıştır.

\section{Veri Toplama Aracı ve Süreci}

Öğretmenlerin mesleklerini yerine getirirken yaşayabileceği iş stresinin ve mesleki tükenmişliğin iş tatmini ve mesleki duygusal bağlılık üzerindeki etkisini ortaya koyabilmek için gerekli veriler, bir anket yardımıyla toplanmıştır. Anketin kapsam ve yapı geçerliliği için uzman akademisyen görüşü alınmıştır. Anket formunun birinci bölümünde öğretmenlere yanıtlamaları için sekiz adet demografik nitelikte soru yöneltilmiştir. Formun ikinci bölümünde ise öğretmenlerden beşli likert ölçek tipinde mesleki tükenmişlik, iş stresi, iş tatmini ve mesleki duygusal bağl1lık ölçekleriyle ilgili toplam 29 soruyu yantlamaları istenmiştir. Toplam 13 maddeden oluşan mesleki tükenmişlik ölçeğinin; duyarsızlaşma (4 madde), duygusal tükenmişlik (3 madde) ve kişisel başarıda azalma (6 madde) olmak üzere üç alt boyutu vardır. İş stresi ve iş tatmini ölçekleri ise 5' er maddeden oluşmaktadır. Mesleki tükenmişlik, iş stresi ve iş tatmini ölçek maddeleri daha önceden güvenirliği test edilmiş bir çalışmadan yararlanılarak oluşturulmuştur (Griffin vd., 2010). Mesleki duygusal bağlllık için ise 6 maddeli bir ölçek (Meyer vd., 1993) kullanılmıştır.

Araştırmac1, Ordu İl Milli Eğitim Müdürlüğünün 06.11.2019 tarih ve 21942620 sayılı izin yazısına istinaden evrende veri toplama işlemine başlanmıştır. 11 Kasım-20 Aralık 2019 tarihleri arasında öğretmenlerle yüz yüze görüşme yapılarak veriler toplanmiştır.

\section{Evren ve Örneklem}

Bu araştırmanın evrenini Ordu ili Altınordu İlçesinde görev yapan 2243 öğretmen oluşturmaktadır. Araştırmanın yapılacağı ilin büyükşehir ve katılımcılara ulaşabilme imkânının kolay olması evren seçiminin temel önceliğidir. Bu evrenden \%95 (0.05) düzeyinde kabul edilebilir asgari örneklem büyüklüğünün sağlanabilmesi için en az 344 katılımcıya, \%99 (0.01) güvenilirlik düzeyinde ise en az 514 katılımcıya ulaşmak gerekmektedir (Gürbüz ve Şahin, 2014). Olasılığa dayalı örneklem yöntemlerinden basit tesadüfi örnekleme yöntemi kullanılarak araştırmanın örnek kütlesi belirlenmiştir. Evrendekilere eşit seçilme imkanı vermek amacıyla araştırma mesai günlerinde ve saatlerinde yapılmıştır. Ayrıca, okulun kamu veya özel ya da okulların niteliği (okul öncesi, ilköğretim, ortaöğretim, vb.) öğretmenlerin branşları, örgütsel ve bireysel özelliklere göre bir ayrım yapılmadan saha çalışması tamamlanmıştır. Anket formundaki soruları evrenden 550 öğretmen yanıtlamayı kabul etmiş ve yanıtlamıştır. Bu sayı, nicel desenli sosyal bilimler alanında gerçekleştirilen araştırmalar için \%99 
güvenilirlik düzeyinde, kabul edilebilir aralıkta bir örneklem büyüklügüüür (Gürbüz ve Şahin, 2014).

Hipotez sonuçlarının ve bulgularının alan yazındaki ve sonraki çalışmalarla kıyaslanabilmesine imkân tanıyabilmek amacıyla bu araştırmanın örneklem grubuyla ilgili bazı demografik bilgilere ihtiyaç duyulmuştur. Örneklem grubunun demografik özellikleri; cinsiyet, medeni durum, idari görev, yaş aralığı, gelir düzeyi, meslekte çalışma süresi ve öğrenim düzeyi Tablo1' de gösterilmiştir. Öğretmenlerin branşlarıyla ilgili bilgilere, sadece metin içerisinde yer verilmiştir.

Tablo 1.

Demografik Özellikler

\begin{tabular}{|c|c|c|c|c|c|c|c|c|}
\hline Cinsiyet & $f$ & $\%$ & Medeni Durum & $f$ & $\%$ & İdari Görevi & $f$ & $\%$ \\
\hline Kadın & 284 & 51,6 & Evli & 498 & 90,5 & Var & 46 & 8,4 \\
\hline Erkek & 266 & 48,4 & Bekâr & 52 & 9,5 & Yok & 504 & 91,6 \\
\hline Yaş Aralığı & $f$ & $\%$ & Gelir Düzeyi & $f$ & $\%$ & $\begin{array}{l}\text { Meslekte Çalışma } \\
\text { Süresi }\end{array}$ & $f$ & $\%$ \\
\hline 25-35 yaş & 81 & 14,7 & $5000 €$ ve altı & 171 & 31,1 & 10 y1l ve altı & 77 & 14,0 \\
\hline 36-45 yaş & 240 & 43,6 & 5001€-6000€ & 195 & 35,5 & $11-20 \mathrm{y} 1 \mathrm{l}$ & 214 & 38,9 \\
\hline 46-55 yaş & 179 & 32,5 & 6001€-7000€ & 109 & 19,8 & $21-30$ y1l & 184 & 33,5 \\
\hline 56 yaş ve üstü & 50 & 9,1 & 7001 € ve üzeri & 75 & 13,6 & 30 yıl ve üzeri & 75 & 13,6 \\
\hline Öğrenim Düzeyi & $f$ & $\%$ & \multicolumn{4}{|c|}{$f:$ frekans } & \multicolumn{2}{|c|}{ \%: yüzde } \\
\hline Lisans & 475 & 86,4 & & & & & & \\
\hline Yüksek Lisans & 73 & 13,3 & & & & & & \\
\hline Doktora & 2 & 0,4 & & & & & & \\
\hline
\end{tabular}

Örneklemi oluşturan 550 öğretmenin demografik özellikleri Tablo 1'deki gibidir. Karşılaştırmalı tablolar (Crosstabs) yönteminden yararlanılarak demografik özellikler yorumlanmıştır. Cinsiyete ile medeni durum incelendiğinde bekârların \%71,2'si kadın, \%28,8'i erkektir. Erkek öğretmenlerin kadın öğretmenlere göre evliliğe daha eğilimli olduğu söylenebilir. Örneklem içerisindekilerin \%90,5’lik kısmının evli olması öğretmenlerin aile olmayı önemsediklerinin bir göstergesidir. Öğretmenlerin gelir düzeyleri, ortalama 5000€ ile 7000€ aralığındadır. \%86,4'ü lisans mezunudur. İdari göreve göre öğrenim durumu karşılaştırıldığında, idari görevi olmayanların idari görevi olanlara göre öğrenim düzeylerinin daha yüksektir. Tüm lisansüstü (yüksek lisans, doktora) öğrenim düzeyleri arasında İdari görevi olanlar \%15,1 iken yönetici ya da idari görevi olmayanlar $\% 84,9^{\prime}$ dur ve doktora mezunu olanlar da bu grubun içerisindedir. Bu sonuç, öğrenim düzeyiyle idari görevlere sahip olma arasında tam bir paralellik olmadığını göstermiştir. İdari görevi olanların \%95'inin hizmet süresi 11 yıl ve üzerindedir. Buradan öğretmenlerin 10 yıldan sonra idari görevde bulunmaya daha istekli oldukları sonucu çıkarılabilir. İdari görevi olanların \%50'si 5000€-6000€, \%38'i ise 6000€'nın üzerinde bir gelir düzeyindedir. İdari görevi bulunmayanların \%66,6's1 6000€'nın altında gelir düzeyindedir ve bunların \%31,1'inin gelir düzeyi 5000€́nın altındadır. Bulgular, gelir düzeyinin öğretmenlerin idari görevlerine göre farklılaştığını, genel olarak idari görevi olanların gelir düzeylerinin daha yüksek olduğunu göstermektedir. Öğretmenlerin yaş aralığı incelendiğinde, orta yaş $(\% 43,6)$ ve üzerindekilerin yoğunlukta olduğu görülmektedir. Bunun nedeni, araştırmanın seçildiği evren olabilir. Çünkü merkezi yerlerde, il merkezlerinde görev 
yapabilmek için öğretmenlerin hizmet alanı ve hizmet puanı gibi kriterler önemlidir. Ayrıca, yaş dağılımını meslekte çalışma süresiyle ilişkilendirildiğinde hizmet alanı ve hizmet puanının belirleyici olduğu söylenebilir. Yaş gruplarıla ilgili bir başka bulgu da şudur; idari ya da yönetici görevi olanların yaş ortalaması genellikle orta yaş ve üzerindeki gruptakilerdir (\%91,3). Araştırmaya katılan öğretmenlerin branşlarındaki çeşitliliğin fazla olması nedeniyle Tablo 1'de branşlarla ilgili bilgilere yer verilememiştir. Branşlarıyla ilgili bulgular incelendiğinde; katılımcıların \%25,81'i (142) sınıf öğretmeni, \%10,9'u (60) Türkçe veya Türk dili ve edebiyatı, \%9,8'i (54) yabancı dil (İngilizce, Almanca, vs.), \%9,81'i (54) matematik, \%5,45'i (30) din kültürü ve ahlak bilgisi, \%4,54'ü (25) okul öncesi öğretmenliği, \%3,45'i (19) tarih, \%3,1'i (17) fen bilimleri, \%3,1 (17) rehberlik ya da rehberlik ve psikolojik danışmanlık, \%2,9'u (16) beden eğitimi, \%2,54'ü (14) fizik, \%2,54'ü (14) kimya, \%2,36 (13) coğrafya, \%2'si (11) müzik, \%1,81'i (10) biyoloji, \%1,63'ü (9) sosyal bilgiler öğretmenliğ̈i, \%1,63'ü (9) bilişim teknolojileri, \%1,45'i (8) görsel sanatlar, \%5,1'i (28) diğer (felsefe, makine, çocuk gelişimi, sağlık hizmetleri, teknoloji tasarım, özel eğitim, otomotiv, tesisat teknolojisi ve iklimlendirme) branşlardır. Branşlardaki dağılımın eğitim sistemindeki önceliklerle ilişkili olduğu söylenebilir. Başka bir ifadeyle eğitim sistemi, okul türleri ve sayısı gibi nitelikler okullardaki derslerin önem düzeyini ya da derslerin zorunlu olmasını, dolaylı olarak da branşlara göre istihdam edilen öğretmen sayısını etkileyebilir.

\section{Verilerin Analizi}

Araştırma verileri, uluslararası araştırmalarda tercih edilen bir yazılım aracılığıyla analiz edilmiştir. Öncelikle, verilerin değişkenlere göre normal dağılıp dağılmadığı incelenmiştir. Skewness ve Kurtosis değerleri -1.5 ile +1.5 arasında ise verilerin normal dağıldığı kabul edilir (Tabachnick ve Fidell, 2013). Bu kapsamda ölçeklerin Skewness değerleri: -1,212 ile 1,342 ve Kurtosis değerleri ise; -,660 ile 1,275 arasındadır. Normallik testine göre, veriler normal dağılmaktadır. $\mathrm{Bu}$ nedenle hipotezler parametrik testlerle sınanmalıdır. Saha araştırması neticesinde toplanan veriler kullanılarak; ölçeklerin niteliklerini, güvenirliğini ve yapısal geçerliliğini test etmek amacıyla güvenirlik ve faktör analizi testleri yapılmıştır. Faktör analizi sonucunda elde edilen değişkenler arasındaki ilişkiler, temel istatistik teknikleri; korelasyon ve çoklu doğrusal regresyon analizleri yardımıyla hesaplanmış ve hipotezlerin testi gerçekleştirilmiştir. Korelasyon analiz testinde Pearson korelasyon katsayısı metodu kullanılmıştır. Çok sayıda değişkenin bulunduğu araştırmalar için en uygun regresyon modelini ortaya koyabilmek için adım adım yöntemi sıklıkla tercih edilmektedir (Alpaykut vd., 2011). Bu araştırmada da hipotezlerin test edilmesi sürecinde adım adım (Stepwise) yöntemi kullanılarak en uygun ve anlamlı regresyon modelinin belirlenmesi amaçlanmıştır.

Güvenirlik analizi. Veri toplama aracının güvenliğini hesaplamak için alfa (a) modeli, Cronbach Alpha güvenilirlik katsayısı kullanılmıştır. Ölçekler için hesaplanan alfa katsayıları sırasıyla; iş tatmini $\alpha=0,79$, mesleki bağlllık $\alpha=0,73$, İş stresi $\alpha=0,78$ ve mesleki tükenmişlik $a=0,65^{\prime}$ dir. Hesaplanan Cronbach Alpha güvenilirlik katsayıları ölçeklerin oldukça güvenilir olduğunu göstermektedir (Kalayc1, 2010).

Faktör analizi. Öğretmenlerle gerçekleştirilen mülakatta; iş stresi, iş tatmini, mesleki bağllıı ve mesleki tükenmişlik ölçekleri kullanılmıştır. Ölçeklerin yapısal geçerliğinin tespiti için temel bileşenler (Principal components) ve Varimax eksen döndürmesi yöntemi kullanılmış ve faktörler isimlendirilmiştir. Faktör sayılarının 
belirlenmesinde tercih edilen ölçüt, Özdeğer (Eigenvalues) istatistiğidir. Veri setlerinin faktör analizine uygunluğunun tespitinde Barlett testi ve Kaiser-Meyer-Olkin (KMO) testlerinden yararlanılmıştır. Faktör yükü (faktör ağırlığ1<0,50) altındaki ölçek maddeleri $(5,17,24)$ çıkarılarak en anlamlı ve bağımsız altı faktör elde edilmiştir. Faktörler, Tablo 2'de maddeleriyle birlikte verilmektedir. Ek1'de, veri toplamak için kullanılan ölçeklere ait maddelerin ifade biçimleri anket formundaki sıraya göre verilmiştir.

Tablo 2.

Faktör Analizi Sonuçlan

\begin{tabular}{|c|c|c|c|c|}
\hline $\begin{array}{c}\text { Mesleki Tükenmişlik Ölçeği } \\
\text { Boyutları ve Maddeleri }\end{array}$ & Faktör Ağırlığ1 & Özdeğer & $\begin{array}{c}\text { Açıklanan } \\
\text { Varyans (\%) }\end{array}$ & $\begin{array}{l}\text { Cronbach } \\
\text { Alpha (a) }\end{array}$ \\
\hline \multicolumn{5}{|l|}{ Kişisel Başarıda Azalma } \\
\hline 12 & ,772 & \multirow{8}{*}{3,673} & \multirow{7}{*}{28,254} & \multirow{6}{*}{806} \\
\hline 11 & 705 & & & \\
\hline 13 & 699 & & & \\
\hline 10 & 695 & & & \\
\hline 9 & 669 & & & \\
\hline 8 & 613 & & & \\
\hline 2 &, 587 & & & ,790 \\
\hline 4 &, 518 & & \multirow[b]{2}{*}{14,836} & \multirow[b]{2}{*}{660} \\
\hline \multicolumn{2}{|l|}{$\begin{array}{l}\text { Duygusal Tükenmişlik } \\
\text { Dus }\end{array}$} & \multirow{4}{*}{$\begin{array}{l}1,928 \\
1,454\end{array}$} & & \\
\hline 7 & 805 & & \multirow{5}{*}{11,182} & \multirow{5}{*}{$a=, 650$} \\
\hline 6 & 796 & & & \\
\hline \multicolumn{2}{|l|}{ Duyarsızlaşma } & & & \\
\hline 3 & 830 & & & \\
\hline \multirow[t]{2}{*}{1} & 820 & & & \\
\hline & Toplam & & $\% 54,266$ & \\
\hline
\end{tabular}

Kaiser-Meyer-Olkin Değeri= ,721; Bartlett Küresellik Testi: [ $\left.\chi^{2}(78)=2437,021 ; p<0.001\right]$

\begin{tabular}{|c|c|c|c|c|}
\hline $\begin{array}{l}\text { Mesleki Duygusal Bağlılık } \\
\text { Ölçeği ve Maddeleri }\end{array}$ & Faktör A Ăırlığ & \multirow[t]{3}{*}{ Özdeğer } & $\begin{array}{l}\text { Açıklanan } \\
\text { Varyans (\%) }\end{array}$ & $\begin{array}{l}\text { Cronbach } \\
\text { Alpha (a) }\end{array}$ \\
\hline 3 & 790 & & \multirow{5}{*}{45,120} & \multirow{5}{*}{,735 } \\
\hline 5 & 781 & & & \\
\hline & 767 & \multirow[t]{3}{*}{2,707} & & \\
\hline 7 & 602 & & & \\
\hline & ,561 & & & \\
\hline
\end{tabular}

Kaiser-Meyer-Olkin Değeri= ,804; Bartlett Küresellik Testi: $\left[x^{2}(15)=712,624 ; p<0.001\right]$

$\begin{array}{lllll}\text { İş Tatmini Ölçeği ve Maddeleri } & \text { Faktör Ağırlığı } & \text { Özdeğer } & \begin{array}{c}\text { Açıklanan } \\ \text { Varyans (\%) }\end{array} & \begin{array}{c}\text { Cronbach } \\ \text { Alpha (a) }\end{array}\end{array}$

\begin{tabular}{|c|c|c|c|}
\hline 22 & 847 & \multirow{4}{*}{2,711} & \multirow{4}{*}{54,223} \\
\hline 21 & 845 & & \\
\hline 23 & 731 & & \\
\hline 20 & 697 & & \\
\hline
\end{tabular}

Kaiser-Meyer-Olkin Değeri= ,782; Bartlett Küresellik Testi: $\left[X^{2}(10)=835,990 ; p<0.001\right]$

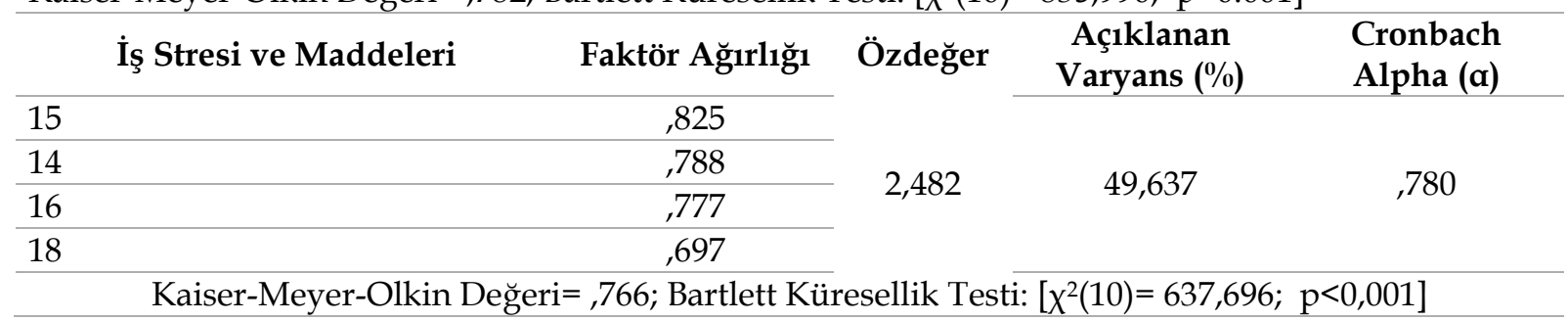




\section{Bulgular}

Örneklemden elde edilen verilerin uygun bir istatistik programı yardımıyla analiz edilmiş ve araştırmanın bulguları ortaya konulmuştur. Araştırmanın hipotezlerini test etmek için çoklu korelasyon ve regresyon analizi yöntemleri temel alınmıştır. Korelasyon analizi sırasında hesaplama yöntemlerinden Pearson korelasyon katsayısı tercih edilmiş ve faktörler arasındaki anlamlı ilişkiler $(p<0,01$ ve $p<0,05)$ düzeylerine göre belirlenmiştir (Tablo 3). Aralarında istatistiksel olarak anlamlı ilişkilerin olduğu tespit edilen değişkenlere, hipotezler kapsamında çoklu doğrusal regresyon analizi uygulanmıştır. Bu analizler sırasında en uygun modelin belirlenmesi amaçlanmış, bu nedenle Stepwise (adım adım) metodu kullanılmıştır.

\section{Korelasyon Analizi Sonucu}

Tablo 3.

Korelasyon Analizi Sonucu

\begin{tabular}{|c|c|c|c|c|c|c|c|c|}
\hline & Ortalama & $\begin{array}{c}\text { Standart } \\
\text { Sapma }\end{array}$ & F1 & F2 & F3 & F4 & F5 & F6 \\
\hline İş Tatmini (F1) & 4,1409 & 0,71410 & 1 & & & & & \\
\hline Mesleki Duygusal Bağlılık (F2) & 4,3312 & 0,72968 & $484^{* *}$ & 1 & & & & \\
\hline İş Stresi (F3) & 1,8086 & 0,70135 &,$- 217^{* *}$ &,$- 169 * *$ & 1 & & & \\
\hline Duyarsılaşma (F4) & 1,6391 & 0,91248 &,$- 235^{\star * *}$ &,$- 166^{* *}$ & ,099* & 1 & & \\
\hline Duygusal Tükenmişlik (F5) & 2,3809 & 1,12550 &,$- 299 * *$ &,$- 323^{* *}$ & $315^{* *}$ & ,053 & 1 & \\
\hline Kişisel Başarıda Azalma (F6) & 1,9955 & 0,63353 &,$- 482^{* *}$ &,$- 284^{* *}$ &, $140^{* *}$ & $277^{* *}$ &, 179 ** & 1 \\
\hline
\end{tabular}

Çoklu korelasyon analizi bulguları, iş tatmini ve mesleki duygusal bağlılığın iş stresi ve mesleki tükenmişlik boyutlarıyla; duyarsızlaşma, duygusal tükenmişlik, kişisel başarıda azalma arasında anlamlı $(* *<0,01)$ ve negatif bir ilişkinin olduğunu göstermektedir. İş tatmini ile mesleki duygusal bağlılık arasında ise anlamlı ve pozitif yönlü bir ilişki vardır $\left(r=, 484^{* *}\right)$. Ayrıca, iş stresiyle mesleki tükenmiş boyutları arasında da istatistiksel olarak anlamlı $\left({ }^{*} p<0,01\right.$ veya ${ }^{*} p<0,05$ düzeylerinde) ve pozitif ilişkinin olduğu sonucuna ulaşılmıştır.

\section{Regresyon Analizi Sonuçları}

Araştırma hipotezlerinin test edilmesi amacıyla gerçekleştirilen çoklu doğrusal regresyon analizi sonuçları tablolar yardımıyla verilmiştir.

Tablo 4.

İş Tatminine ilişkin Regresyon Analizi Sonuçları

\begin{tabular}{|c|c|c|c|c|c|}
\hline \multirow{2}{*}{ İş Tatmini Bă̆ımlı Değişken } & \multicolumn{2}{|c|}{$\begin{array}{c}\text { Standartlaştırılmamış } \\
\text { Katsayılar }\end{array}$} & \multirow{2}{*}{$\begin{array}{c}\text { Standartlaştırılmış } \\
\text { Katsayılar } \\
\operatorname{Beta}(\beta)\end{array}$} & \multirow[t]{2}{*}{$t$} & \multirow{2}{*}{$p$} \\
\hline & $B$ & Standart Hata & & & \\
\hline Sabit & 5,666 & 0,107 & & 53,023 & 0,000 \\
\hline Kişisel Başarıda Azalma & $-0,448$ & 0,043 & $-0,397$ & $-10,427$ & 0,000 \\
\hline Duygusal Tükenmişlik & $-0,132$ & 0,024 & $-0,208$ & $-5,408$ & 0,000 \\
\hline Duyarsızlaşma & $-0,100$ & 0,029 & $-0,127$ & $-3,383$ & 0,001 \\
\hline İş Stresi & $-0,085$ & 0,039 & $-0,083$ & $-2,184$ & 0,029 \\
\hline$R^{2}=, 301$ & Model & $, 029<0,05$ & Durbin-Watson $=2,031$ & & \\
\hline
\end{tabular}


Tablo 4'teki regresyon modelinin anlamlı olduğu ve tüm bağımsız değişkenlerin; iş stresi, kişisel başarıda azalma, duygusal tükenmişlik ve duyarsızlaşma iş tatminindeki \%30 oranındaki varyansı açıkladığ1 görülmüştür $\left(R^{2}=\right.$ $0,301 ; F=4,772 ; p<0,05)$. Bulgulara göre; öğretmenlerin iş tatmini üzerinde, iş stresinin $(\beta=-, 085 ; p<0.05)$ ve mesleki tükenmişlik boyutlarının; Kişisel başarıda azalma $(\beta=-$ ,397; $p<0,001)$, Duygusal tükenmişlik $(\beta=-, 208 ; p<0,001)$ ve Duyarsızlaşma $(\beta=-, 127$; $p<0,001)$ negatif yönlü bir etkisi vardır. Öğretmenlerin iş tatmini üzerinde en büyük değişime neden olan faktörün kişisel başarıdaki azalmadır $(\beta=-, 397 ; \quad p<0,001)$. Yukarıdaki regresyon analizi sonucunda; Hipotez1, Hipotez 3a, Hipotez 3b ve Hipotez 3c kabul edilmiştir.

Tablo 5.

Mesleki Duygusal Bă̆hlı̆̆a İlişkin Regresyon Analizi Sonuçlan

\begin{tabular}{|c|c|c|c|c|c|}
\hline \multirow{2}{*}{$\begin{array}{l}\text { Mesleki Duygusal Bağhlık } \\
\text { Bağımlı Değişken }\end{array}$} & \multicolumn{2}{|c|}{$\begin{array}{c}\text { Standartlaştırılmamış } \\
\text { Katsayılar }\end{array}$} & \multirow{2}{*}{$\begin{array}{c}\begin{array}{c}\text { Standartlaştırılmış } \\
\text { Katsayılar }\end{array} \\
\text { Beta }(\beta)\end{array}$} & \multirow[t]{2}{*}{$t$} & \multirow{2}{*}{$p$} \\
\hline & $B$ & Standart Hata & & & \\
\hline Sabit & 3,052 & 0,215 & & 14,195 & 0,000 \\
\hline İş Tatmini & 0,412 & 0,040 & 0,403 & 10,191 & 0,000 \\
\hline Duygusal Tükenmişlik & $-0,134$ & 0,025 & $-0,207$ & $-5,366$ & 0,000 \\
\hline Duyarsızlaşma & $-0,066$ & 0,030 & $-0,082$ & $-2,175$ & 0,030 \\
\hline
\end{tabular}

Mesleki duygusal bağlılık üzerinde iş tatmini, duygusal tükenmişlik, duyarsızlaşma, kişisel başarıda azalma ve iş stresi bağımlı değişkenlerinin anlamlı bir etkisinin bulunup bulunmadı $\breve{g} 1$ regresyon analiziyle test edilmiştir. Analiz sonucunda, en anlamlı bulunan regresyon modeli Tablo 5 'teki gibidir. Bu regresyon modeline göre mesleki duygusal bağlllık üzerinde iş tatmininin pozitif $(\beta=, 403 ; p<0,001)$ etkisi, duygusal tükenmişlik $(\beta=-, 207 ; p<0,001)$ ve duyarsızlaşmanın $(\beta=-, 082 ; p<0,005)$ ise negatif etkisi vardır. Başka bir ifadeyle regresyon modeline anlamlı katkısı bulunan bağımsız değişkenler; iş tatmini, duygusal tükenmişlik ve duyarsızlaşmadır. Mesleki duygusal bağlılık üzerinde, anlamlı en büyük etkiyi iş tatmini değişkeni yapmaktadır. İş tatmini, duygusal tükenmişlik ve duyarsızlaşma değişkenleri, mesleki duygusal bağlılıktaki \%27,5 oranındaki varyansı açıklayabilmektedir. Diğer taraftan mesleki duygusal bağlılık üzerinde iş stresinin ve kişisel başarıda azalmanın anlamlı bir etkisi bulunamamıştır. Mesleki duygusal bağlılıkla ilgili regresyon analizi sonucunda; Hipotez $4 \mathrm{a}$, Hipotez $4 \mathrm{~b}$ ve Hipotez 5 kabul edilmiştir. Hipotez 2 ve Hipotez $4 \mathrm{c}$ ise reddedilmiştir.

Ayrıca, iş tatmininin regresyon analizine dahil edilmediği, iş stresinin ve mesleki tükenmişlik boyutlarının mesleki duygusal bağlılık üzerindeki etkisinin araştırıldığı durumda ise; mesleki tükenmişlik boyutlarının; duygusal tükenmişlik ( $\beta=$ -,294; $p<0,001)$, kişisel başarıda azalma $(\beta=-, 196 ; p<0,001)$ duyarsılaşma $(\beta=-, 127$; $p<0,005)$ mesleki duygusal bağlılık üzerinde anlamlı ve negatif yönlü bir etkisinin olduğu sonucuna ulaşılmıştır (Tablo 6). Bu analiz sonucunda da mesleki duygusal bağlılık üzerinde, iş stresinin anlamlı bir etkisinin olmadığı görülmüştür. 
Tablo 6.

Mesleki Duygusal Bă̆lılı̆̆a İlişkin Regresyon Analizi Sonuçları

\begin{tabular}{|c|c|c|c|c|c|}
\hline \multirow{2}{*}{$\begin{array}{l}\text { Mesleki Duygusal Bă̆lılık } \\
\text { Bağımlı Değişken }\end{array}$} & \multicolumn{2}{|c|}{$\begin{array}{c}\text { Standartlaştırılmamış } \\
\text { Katsayılar }\end{array}$} & \multirow{2}{*}{\begin{tabular}{|c|}
$\begin{array}{c}\text { Standartlaştırılmış } \\
\text { Katsayılar }\end{array}$ \\
Beta $(\beta)$
\end{tabular}} & \multirow[t]{2}{*}{$t$} & \multirow{2}{*}{$p$} \\
\hline & $B$ & Standart Hata & & & \\
\hline Sabit & 5,403 & 0,109 & & 49,569 & 0,000 \\
\hline Duygusal Tükenmişlik & $-0,191$ & 0,026 & $-0,294$ & $-7,391$ & 0,000 \\
\hline Kişisel Başarıda Azalma & $-0,226$ & 0,048 & $-0,196$ & $-4,733$ & 0,000 \\
\hline Duyarsızlaşma & $-0,102$ & 0,033 & $-0,127$ & $-3,121$ & 0,002 \\
\hline
\end{tabular}

\section{Tartışma}

Alan yazında, iş stresi, mesleki tükenmişlik, iş tatmini ve duygusal bağlılık değişkenleri arasındaki ilişkiyi mesleki boyutta ele alan ve araştıran çalışmalar bulunmaktadır. Bu çalışmalarda, iş stresi ile iş tatmini arasındaki ilişkiyi ortaya koymak için özel ve kamu alanlarından değişik meslek grupları örnek seçilmiştir. Bu araştırmalardan çıkarılan genel sonuç, iş stresinin ya da mesleki stresin tatmini ve örgütsel veya mesleki duygusal bağlılıkla negatif ilişkisinin olduğudur (Lambert vd., 2005; Griffin vd., 2010; Aghdasi vd., 2011; Lin vd., 2013; Wang vd., 2014; Güner vd., 2014; Akova vd., 2015; Kuo, 2015; Sharma ve Chalotra, 2017; Bayar ve Öztürk, 2017; Yang vd., 2017; Mullen vd., 2018; Lambert vd., 2018; Lambert vd., 2018; Turhan vd., 2018). Benzer şekilde alan yazında, iş ya da mesleki tükenmişliğin iş tatmini ve duygusal bağlılık ile arasında istatistiksel olarak anlamlı bir ilişkinin bulunduğu ifade edilmektedir. Tükenmişliğin iş tatmini ve duygusal bağlılıkla arasındaki ilişkinin zıt yönde olduğu da araştırmaların genel sonuçlardandır (Griffin vd., 2010; Çifçioğlu, 2011; Salehi ve Gholtash, 2011; Wang vd., 2014; Garland vd., 2014; Lambert vd., 2018; Mullen vd., 2018). Tükenmişliğin iş tatmini ve duygusal bağlılık değişkenleriyle arasındaki bu genel ilişkinin öğretmenlik mesleğini yerine getirenler için de geçerli olup olmadığının incelenmesi bu çalışmanın amaçlarındandır. Çalışanların yaşadıkları iş tatmininin mesleki ve örgütsel bağlılıkla arasında pozitif ilişkisinin olduğu, iş tatmininin çalışan bağlılığını etkilediği özellikle sosyal bilimler alanındaki araştırmalarla ortaya konulmuştur (Irving vd., 1997; Griffin vd., 2010; Salehi ve Gholtash, 2011; Yousaf vd., 2013; Kuo, 2015; Turhan vd., 2018; Lambert vd., 2018; Salzmann vd., 2018).

\section{Sonuç ve Öneriler}

Öğretmenler üzerinde yapılan bu araştırmanın bulguları, önceki araştırmaların bulgularıyla büyük ölçüde benzerlik göstermektedir. Bu araştırmada, iş stresi ve mesleki tükenmişlik boyutları (duyarsızlaşma, kişisel başarıda azalma ve duygusal tükenmişlik) ile öğretmenlerin iş tatmini arasında anlamlı ve negatif bir ilişkinin olduğu sonucuna ulaşılmıştır. Regresyon analiz sonucunda, iş stresinin ve mesleki tükenmişlik boyutlarının iş tatmini üzerinde anlamlı ve negatif etkisinin olduğu görülmüştür. Başka bir ifadeyle bu araştırmaya göre, iş tatminini açıklamada iş stresinin ve mesleki tükenmişlik boyutlarının anlamlı katkısı vardır. İş tatmini üzerinde en anlamlı katkısı bulunan bağımsız değişken, kişisel başarıda azalmadır ( $\beta=$ -,397; $p<0,001)$. Diğer bağımsız değişkenlerin iş tatminine anlamlı katkısı sırasıyla; 
duygusal tükenmişlik $(\beta=-, 208 ; p<0,001)$, duyarsızlaşma $(\beta=-, 127 ; p<0,001)$ ve iş stresi $(\beta=-, 085 ; p<0.05)$ şeklinde olmuştur.

Öğretmenlerin mesleki duygusal bağlılığı ile iş stresi ve mesleki tükenmişlik boyutları arasındaki ilişkiler incelendiğinde de iş tatminindekine benzer sonuçlara ulaşılmıştır. İş stresi, duyarsızlaşma, duygusal tükenmişlik ve kişisel başarıda azalma ile mesleki duygusal bağlılıkla arasında anlamlı $(p<0,01)$ ve negatif yönlü bir ilişkinin olduğu bulunmuştur. Mesleki duygusal bağlllıkla iş tatmini arasında ise pozitif yönlü bir ilişkinin olduğu tespit edilmiştir. Korelasyon analizi sonucunda, bağımlı (mesleki duygusal bağlılık) ve bağımsız değişkenler (iş stresi, duyarsızlaşma, duygusal tükenmişlik ve kişisel başarıda azalma) arasında anlamlı ilişkilerin olduğu belirlenmişse de regresyon analizi sonucunda bazı bağımsız değişkenlerin mesleki duygusal bağlılık üzerinde anlamlı bir katkısının bulunmadığ1 görülmüştür. Regresyon analiz sonucuna göre; mesleki duygusal bağlılık üzerinde iş tatmininin pozitif, duyarsızlaşma ve duygusal tükenmişliğin ise negatif etkisi vardır. Bu araştırmaya göre, öğretmenlerin mesleki duygusal bağl1lı̆̆1 üzerinde en anlamlı katkıyı, en önemli etkiyi iş tatmini yapmaktadır $(\beta=, 403 ; p<0,001)$. Diğerleri sırasılyla; duygusal tükenmişlik $(\beta=-, 207 ; \mathrm{p}<0,001)$ ve duyarsızlaşmadır $(\beta=-, 082 ; p<0,005)$. Ancak, bu analiz sonucunda iş stresinin ve kişisel başarıdaki azalmanın mesleki duygusal bağlılık üzerinde anlamlı bir etkisi bulunamamıştır.

$\mathrm{Bu}$ çalışmadaki bulgulardan hareketle bazı önerilerde bulunulmuştur. Öğretmenler, işlerinden tatmin olduklarında ve yüksek düzeyde iş tatmini yaşadıklarında, öğretmenlerin mesleklerine karşı hissettiği duygusal bağlılığı da doğru orantılı bir şekilde artabilir. $\mathrm{Bu}$ araştırmaya göre, iş stresi ve mesleki tükenmişlik iş tatminini negatif bir şekilde etkimektedir. Dolayısıyla öğretmenlerin iş stresi yaşamalarına ve meslekleriyle ilgili tükenmişliklerine neden olan temel ya da muhtemel faktörler ilgili kurum ve kuruluşlar tarafından belirlenmeli, bu faktörlerin etkisinin ortadan kaldırılması sağlanmalı veya etkilerin öğretmenlerce asgari düzeyde hissedilmesi için önlemler alınmalıdır. Böyle yaklaşımlarla öğretmenlerin mesleklerinden tatmin olmaları sağlanabilir. Bu meslektekilerin tatminlik duygusundaki artışlar, dolaylı olarak da öğretmenlerin daha yüksek düzeyde mesleki duygusal bağlılı yaşamalarına yardımcı olabilir. Duyguları motive olmuş öğretmenler, bireysel performanslarını artırarak kurumsal verimliliğe katkı sağlayabilir. Daha uzun süre, örgütsel sadakatle örgütte görev yapabilirler. Çünkü bu araştırma, öğretmenlerin mesleki duygularının önemli olduğunu göstermiştir. Ayrıca, öğretmenlik, çocuk ve genç yaştaki bireylerle büyük ölçüde yüz yüze iletişim kurmayı gerektiren, bireysel ve örgütsel nitelikli bir meslektir. Bu sebeple, mesleğini yerine getirirken öğretmenlerin karşı karşıya kaldığı, yaşadığı olumlu (iş tatmini, mesleki duygusal bağlılık) ve olumsuz (iş stresi ve mesleki tükenmişlik) gibi durumlar, öğretmenlerin insanlarla olan bireysel ve örgütsel düzeydeki iletişimini etkileyebilir. Olumlu, iyi bir iletişim, öğretmenlerin ve öğrencilerin bireysel performansını ve verimliliğini, öğretmenlerin kendi aralarındaki ve örgüte yönelik davranışlarını olumlu yönde etkileyebilir. Bireysel ve kurumsal başarı artabilir. Bu konuda, özellikle özel eğitim kurumlarındaki öğretmenlerin algıladığ1 ve yaşadığı mesleki ve örgütsel duygular ayrı bir önem arz edebilir. İş stresi, iş tatmini, mesleki bağlılık ve özdeşleme, örgütsel vatandaşlık davranışı ve tükenmişlik vb. konular öğretmenleri, dolaylı bir şekilde öğrencileri etkilediği gibi eğitim sektöründe faaliyet gösteren özel işletmelerin 
stratejisini, amaçlarını ve geleceğini de doğrudan ya da dolaylı olarak etkileyebilir. Örneğin, bir özel eğitim kurumunun sürdürülebilir rekabet avantajını, kurumsal imajını, verimliliğini ve performansını, müşteri talebini ve insan kaynağını etkileyebilir.

İş stresi ve mesleki tükenmişlik boyutlarından başka; örgütsel vatandaşlık, örgütsel adalet, örgütsel yabancılaşma, örgütsel sessizlik, sinizm gibi meslek ve örgüt kaynaklı diğer faktörler de öğretmenlerin iş tatminini ve mesleki duygusal bağlılı̆̆ını etkileyebilir. Regresyon analizi sonucundaki açılanan varyans oranı bunun bir göstergesidir. Diğer faktörlerin de bulunduğu daha spesifik modeller oluşturularak yeni araştırmalar yapılabilir. Böylece, öğretmenlerin başarılarına engel olabilecek güncel sorunların tespiti yapılabilir ve bu sorunlara çözüm üretilebilir. Çünkü, bir öğretmenin mesleğiyle ilgili düşüncelerini, hislerini ekonomik, sosyal ve çevresel faktörler de etkileyebilir. Örneğin, ek ders saati ve ücreti, yöneticilerin baskıcı ve hoşgörüsüz tutumu, öğrencilerin niteliği, eğitim sistemi uygulamalarındaki eksiklikler, haksız yere öğrenci velilerinin öğretmenlere baskı uygulaması gibi faktörler öğretmenin iş stresi yaşamasına, kendini yalnız ve mutsuz hissetmesine, mesleğinden tatmin olmamasına, severek ve çok iyi yaptığı mesleğinden vazgeçmesine neden olabilir.

Öğretmenlerin saygınlığını artırıcı farkındalık projeleri geliştirmek, öğretmenlerin mesleki görevlerini en iyi şekilde yapabilmesini sağlayacak araç ve gereçleri tedarik etmek, örgütsel ve yönetsel düzeyde motivasyonu düşürücü, mesleki tükenmişliğe ve iş stresinin yaşanmasına sebep olabilecek olası durumları önlemek, tespit etmek ve ortadan kaldırmak, kurumsal, mesleki, ekonomik ve çevresel şartların iyileştirilmesini sağlamak, mesleki tatmini ve örgütsel bağlılığı artırıcı örgütsel ortamı oluşturmak, eğitim kurumlarının başarısı için gereken temel yaklaşımlar olarak görülebilir.

\section{Kaynakça}

Aghdasi, S., Kiamanesh, A. and Ebrahim, A. (2011). Emotional Intelligence and Organizational Commitment: Testing the Mediatory Role of Occupational Stress and Job Satisfaction. Procedia - Social and Behavioral Sciences, 29, 19651976. https:// doi.org/10.1016/j.sbspro.2011.11.447

Akova, O., Emiroglu, B. ve Tanriverdi, H. (2015). İş stresi ile çalışanların iş tatmini ve işten ayrılma niyeti arasındakı ilişki: istanbul' daki 5 yıldızlı otel işletmelerinde bir araştırma. Journal of Management, Marketing $\mathcal{E}$ Logistics, 2(4), 378-402.

Alpaykut, S., Firuzan, A. ve Kuvvetli, Ü. (2011). Çok değişkenli kalite kontrolde regresyon düzeltmesi. Dokuz Eylül Üniversitesi Sosyal Bilimler Enstitüsü Dergisi, 13(2), 31-41.

Bayar, H. ve Öztürk, M. (2017). İş stresinin iş tatmini üzerindeki etkisi: süleyman demirel üniversitesi araştırma görevlileri üzerine bir araştırma. Süleyman Demirel Üniversitesi İktisadi ve İdari Bilimler Fakültesi Dergisi, 22(2), 525-546.

Çiftçioglu, A. (2011). Investigating occupational commitment and turnover intention relationship with burnout syndrome. Business and Economics Research Journal, 2(3), 109-119. https:/ / doi.org/10.1504/IJAF.2011.043846

Ertürk, E. ve Keçecioğlu, T. (2012). Çalışanların iş doyumları ile mesleki tükenmişlik düzeyleri arasındaki ilişkiler: öğretmenler üzerine örnek bir uygulama. Ege Akademik Bakış, 12(1), 39-52. https:/ / doi.org/10.21121/eab.2012119545 
Fırat, Z. (2018). Mesleki doyum, iş-aile çatışması ve aile-iş çatışmasının algılanan iş stresi üzerindeki etkisi. Yönetim Bilimleri Dergisi, 16(32), 157-176.

Garland, B., Lambert, E., Hogan, N., Kim, B. and Kelley, T. (2014). The relationship of affective and continuance organizational commitment with correctional staff occupational burnout: A partial replication and expansion study. Criminal Justice and Behavior, 41(10), 1161-1177. https: / / doi.org/10.1177/0093854814539683

Griffin, M., Hogan, N., Lambert, E., Tucker-Gail, K. and Baker, D. (2010). Job involvement, job stress, job satisfaction, and organizational commitment and the burnout of correctional staff. Criminal Justice And Behavior, 37(2), 239-255. https:// doi.org/10.1177/0093854809351682

Güçlü, N. ve Zaman, O. (2011). Alan dışından atanmış rehber öğretmenlerin iş doyumları ile örgütsel bağlılıkları arasındaki ilişki. Türk Eğitim Bilimleri Dergisi, 9(3), 541-576.

Günbayı, İ. ve Tokel, A. (2012). İlköğretim okulu öğretmenlerinin iş doyumu ve iş stresi düzeylerinin karşılaştırmalı analizi. Ordu Üniversitesi Sosyal Bilimler Araştırmaları Dergisi, 3(5), 77-95.

Güner, F., Çiçek, H. ve Can, A. (2014). Banka çalışanlarının mesleki stres ve tükenmişlik düzeylerinin iş doyumu ve yaşam doyumu düzeyleri ile ilişkisi. Uluslararası Alanya İşletme Fakültesi Dergisi, 6(3), 59-76.

Gürbüz, S. ve Şahin, F. (2014). Sosyal bilimlerde araştırma yöntemleri felsefe-yöntemanaliz. Ankara: Seçkin Yayıncılık.

Hurst, T. and Hurst, M. (1997). Gender differences in mediation of severe occupational stress among correctional officers. American Journal of Criminal Justice, 22(1), 121-137. https:/ / doi.org/10.1007/BF02887343

Irving, P., Coleman, D. and Cooper, C. (1997). Further assessments of a threecomponent model of occupational commitment: generalizability and differences across occupations. Journal of Applied Psychology, 82(3), 444-452. https:/ / doi.org/10.1037/0021-9010.82.3.444

Kalaycı, Ş. (2010). Spss çok değişkenli istatistik teknikleri. Ankara: Asil Yayın Dağıtım.

Kuo, S. Y. (2015). Occupational stress, job satisfaction, and affective commitment to policing among taiwanese police officers. Police Quarterly, 18(1), 27-54. https:// doi.org/10.1177/1098611114559039

Lambert, E., Hogan, N., Paoline, E. and Clarke, A. (2005). The impact of role stressors on job stress, job satisfaction, and organizational commitment among private prison staff. Security Journal, 18(4), 33-50. https:// doi.org/10.1057/palgrave.sj.8340210

Lambert, E., Qureshi, H., Frank, J., Klahm, C. and Smith, B. (2018). Job stress, job involvement, job satisfaction, and organizational commitment and their associations with job burnout among indian police officers: A research note. Journal of Police and Criminal Psychology, 33(2), 85-99. https:// doi.org/10.1007/s11896-017-9236-y

Lapointe, É., Morin, A., Courcy, F., Boilard, A. and Payette, D. (2011). Workplace affective commitment, emotional labor and burnout: A multiple mediator model. International Journal of Business and Management, 7(1), 3-21. https:// doi.org/10.5539/ijbm.v7n1p3 
Lin, J.-Y., Lin, C.-J. and Cheng, C.-J. (2013). A study of the relationship between job stress, job burnout, job satisfaction and organizational commitment among medical radiologists in Taiwan. Journal of Information and Optimization Sciences, 34 (2-3), 149-167. https:/ / doi.org/10.1080/02522667.2013.821334

Maslach, C. and Jackson, S. (1981). The measurement of experienced burnout. Journal of Occupational Behaviour, 2, 99-113. https://doi.org/10.1002/job.4030020205

Meyer, J. and Allen, N. (1991). A three-component conceptualization of organizational commitment. 1(1), 61-89. https:/ / doi.org/10.1016/10534822(91)90011-Z

Meyer, J., Allen, N. and Smith, C. (1993). Commitment to organizations and occupations: extension and test of a three-component conceptualization. Journal of Applied Psychology, 78(4), 538-551. https:/ / doi.org/10.1037/00219010.78.4.538

Mowday, R., Steers, R. and Porter, L. (1979). The measurement of organizational commitment. Journal of Vocational Behavior, 14, 224-247. https:// doi.org/10.1016/0001-8791(79)90072-1

Mullen, P., Blount, A., Lambie, G. and Chae, N. (2018). School counselors' perceived stress, burnout, and job satisfaction. Professional School Counseling, 21(1), 1-10. https:// doi.org/10.1177/2156759X18782468

Salehi, M. and Gholtash, A. (2011). The relationship between job satisfaction, job burnout and organizational commitment with the organizational citizenship behavior among members of faculty in the islamic azad university -first district branches, in order to provide the appropriate model. Procedia Social and Behavioral Sciences, 15, 306-310. https:/ / doi.org/10.1016/j.sbspro.2011.03.091

Salzmann, P., Berweger, S. and Ark, T. (2018). Apprentices' affective occupational commitment during vocational education and training: A latent growth curve analysis. Journal of Career Development, 45(4), 315-329.

https:/ / doi.org/10.1177/0894845317696806

Sharma, V. and Chalotra, A. K. (2017). Job stress, job burnout and job satisfaction: a study of call centres in jammu and kashmir. Pranjana: The Journal of Management Awareness, 20(2), 51-58. https:/ / doi.org/10.5958/09740945.2017.00015.2

Spector, P. (1999). Industrial and Organizational Psychology: Research and Practice. New York: John Wiley \& Sons.

Tabachnick, B. and Fidell, L. (2014). Using multivariate statistics. Boston: Pearson.

Turhan, M., Erol, Y., Demirkol, M. and Özdemir, T. (2018). Örgütsel bağl1lık, iş doyumu ve iş stresi arasındaki ilişki. Turkish Studies, 13(27), 1491-1507. https:// doi.org/10.7827/TurkishStudies.14328

Wang, Y., Zheng, L., Hu, T. and Zheng, Q. (2014). Stress, burnout, and job satisfaction: case of police force in china. Public Personnel Management, 43(3), 325-339. https:/ / doi.org/10.1177/0091026014535179

Yang, T., Guo, Y., Ma, M., Li, Y., Tian, H. and Deng, J. (2017). Job stress and presenteeism among chinese healthcareworkers: the mediating effects of affective commitment. International Journal of Environmental Research and Public Health, 14(9), 1-14. https:/ / doi.org/10.3390/ijerph14090978 
Yousaf, A., Sanders, K. and Shipton, H. (2013). Proactive and politically skilled professionals: What is the relationship with affective occupational commitment? Asia Pacific Journal of Management, 30(1), 211-230. https:/ / doi.org/10.1007/s10490-011-9253-9

Yürür, S. ve Keser, A. (2010). İşe bağl1 gerginlik ile iş tatmini ilişkisinde duygusal tükenmenin aracı rolü. Ankara Üniversitesi SBF Dergisi, 65(4), 165-193. https://doi.org/10.1501/SBFder_0000002189

\section{Ek1: Anket Formu}

\begin{tabular}{|c|c|}
\hline 1 & Bazı öğrencilere bir nesne gibi davrandığımı hissediyorum. \\
\hline 2 & İş arkadaşlarıma karşı daha duyarlı olduğumu hissediyorum. \\
\hline 3 & İş yerinde, bazı meslektaşlarıma çok daha az sempatik davranmaktayım. \\
\hline 4 & Okulda, çoğu zaman tüm öğrencilere ve çalışanlara saygılı davranırım. \\
\hline 5 & Başka insanlarla çalışmak beni duygusal olarak gerginleştirir. \\
\hline 6 & İşimden dolayı tükenmişlik yaşadığımı hissediyorum. \\
\hline 7 & İşteki günün sonunda duygusal tükenmişlik yaşıyorum. \\
\hline 8 & Çalışma arkadaşlarımın benim desteğime değer verdiğini hissediyorum. \\
\hline 9 & Okulda, sorunların giderilmesinde etkili olduğumu düşünüyorum. \\
\hline 10 & Bu okulda, olumlu bir etkiye sahip olduğumu hissediyorum. \\
\hline 11 & Öğrencilerin sorunlarıyla etkili bir şekilde başa çıkabilecek yeteneğim var. \\
\hline 12 & Okuldaki görevlerimle öğrencileri olumlu bir şekilde etkilediğimi hissediyorum. \\
\hline 13 & Okulda öğrencilerle birlikte rahat bir ortam oluşturduğuma inanıyorum. \\
\hline 14 & İşim, genellikle hayal kırıklığı yaşamama ve sinirlenmeme neden olur. \\
\hline 15 & İşte genellikle çok fazla baskı altında olurum. \\
\hline 16 & İşteyken genellikle gergin ya da telaşlı olduğumu hissederim. \\
\hline 17 & Çalışırken genelde sakin ve huzurluyum. \\
\hline 18 & İşimin beni üzen birçok yönü var. \\
\hline 19 & İşimi kesinlikle sevmem. \\
\hline 20 & İşimi ortalama bir öğretmenin sevdiğinden daha çok seviyorum. \\
\hline 21 & Çoğu gün, işimi yapmaya hevesliyimdir. \\
\hline 22 & İşimde beni mutlu eden bir yön mutlaka bulurum. \\
\hline 23 & İşimden oldukça iyi tatmin olduğumu hissediyorum. \\
\hline 24 & Öğretmenlik mesleği kendi imajım için önemlidir. \\
\hline 25 & Öğretmenlik mesleğini yapmaktan dolayı pişmanım. \\
\hline 26 & Öğretmenlik mesleğinde olduğum için gururluyum. \\
\hline 27 & Öğretmen olmak beni mutlu etmiyor. \\
\hline 28 & Öğretmenlik yapmaya istekliyim. \\
\hline 29 & Kendimi öğretmenlik mesleğiyle özdeşleştiremiyorum. \\
\hline
\end{tabular}

\section{Summary}

\section{Introduction}

Educational institutions are among the largest and most important organizations that countries have. The majority of the human resource of this organization is composed of teachers of different expertise who directly serve the purpose of the organization. Teachers are the main organization members that directly contribute and influence the future of the youth of a country. Teachers are among the important and valuable individuals of the society. For this reason, it is important to know the emotions experienced by teachers who have a large share in the education of future scientists, to take steps to eliminate them if they have negative emotions in professional context, and to ensure the continuity of their positive feelings, both for the productivity of the students educated by the teachers and the organizations where these students will 
work. Because the teaching profession is a rare and special task where close and continuous communication is established with young individuals and students throughout the day. In addition, those who fulfill this profession may be affected by the organization inside and outside. In short, the necessity and characteristics of the profession can lead to the development of different feelings and feelings in teachers and the emergence of new behaviors. For example, emotions and behaviors such as job stress, burnout (depersonalization, emotional exhaustion, decreased personal accomplishment), job satisfaction and commitment, performance, organizational commitment and citizenship behavior are some of these. Therefore, it is a necessity of scientific research to determine the effect of professional quality, organizational environment and the environment outside the organization on employees, to reveal and explain the results together with the reasons, and to develop solutions to problems. This study deals with the relationships between the concepts of job stress, job satisfaction, occupational burnout, and occupational affective commitment within the framework of the teaching profession.

\section{Method}

This paper aims to examine the relationships between the job stress, occupational burnout, job satisfaction and occupational affective commitment factors that teachers' experience while performing their duties.

Data were collected using the quantitative research method. Teachers in public and private schools in Altınordu District of Ordu Provincial Directorate of National Education constitute the population of the research. The research was carried out between 11 November and 20 December 2019. The sample of this research is 550 teachers who answer the questions in the data collection tool. The sample of this research consists of 550 teachers who answer the survey questions. The survey contains 37 questions in total. These questions include 8 demographic and 29 fivepoint Likert scale items.

\section{Results}

As a result of the research, the following findings were reached: There is a significant and negative relationship between job satisfaction and occupational affective commitment and job stress and occupational burnout dimensions (decrease in personal accomplishment, depersonalization, emotional exhaustion). A positive relationship was found between job satisfaction and occupational affective commitment. A positive relationship was found between job satisfaction and occupational affective commitment. Job stress and occupational burnout dimensions have a significant and negative effect on job satisfaction. Job satisfaction has a positive effect on occupational affective commitment. It was concluded that emotional exhaustion and depersonalization have a negative effect on occupational affective commitment. On the other hand, there was no significant effect of job stress and decrease in personal accomplishment on occupational affective commitment. The main factors that cause teachers to experience work stress and occupational burnout should be identified, eliminated or the effects of these factors should be minimized. In this way, teachers' job satisfaction and affective commitment to their occupational can be partially increased. 


\section{Discussion}

In the literature, there are studies that examine and investigate the relationship between job stress, occupational burnout, job satisfaction and affective commitment on a occupational scale. In order to reveal the relationships between job stress and job satisfaction, it is seen that different professional groups are chosen as examples in private and public fields. The general conclusion in these studies is that job stress or occupational stress has a negative influence and relationship with both job satisfaction or satisfaction, and organizational or occupational affective commitment (Lambert et al., 2005; Griffin et al., 2010; Aghdasi et al., 2011; Lin et al., 2013; Wang et al., 2014; Güner et al., 2014; Akova et al., 2015; Kuo, 2015; Sharma \& Chalotra , 2017; Bayar and Öztürk, 2017; Yang et al., 2017; Mullen et al., 2018; Lambert et al., 2018; Lambert et al., 2018; Turhan et al., 2018). Similarly, in the literature, it is generally mentioned that there is a statistically significant relationship between job or occupational burnout, job satisfaction and affective commitment. It is also one of the general results that the relationship between burnout and job satisfaction and affective commitment is opposite (Griffin et al., 2010; Ciftcioglu, 2011; Salehi \& Gholtash, 2011; Wang et al., 2014; Garland et al., 2014; Lambert et al., 2018; Mullen et al., 2018). It has been proven by research conducted in many fields of social sciences that job satisfaction of employees has positive influence and relationship with affective commitment in occupational and organizational context (Irving et al., 1997; Griffin et al., 2010; Salehi \& Gholtash, 2011; Yousaf et al., 2013; Kuo, 2015; Turhan et al., 2018; Lambert et al., 2018; Salzmann et al., 2018). The findings of this study conducted on teachers generally showed similarities with the findings of the previous studiesy.

\section{Pedagogical Implications}

When teachers are satisfied with their job and experience a high level of job satisfaction, teachers' affective commitment to their occupational may increase in direct proportion. According to this research, job stress and occupational burnout negatively affect job satisfaction. Therefore, the basic or possible factors that cause teachers to experience job stress and occupational burnout related to their professions should be determined by the relevant institutions and organizations, the effect of these factors should be eliminated or measures should be taken to make the effects felt by teachers at a minimum level.

\section{Araştırmanın Etik Taahhüt Metni}

Yapılan bu çalışmada bilimsel, etik ve alıntı kurallarına uyulduğu; toplanan veriler üzerinde herhangi bir tahrifatın yapılmadığı, karşılaşılacak tüm etik ihlallerde "Cumhuriyet Uluslararası Eğitim Dergisi ve Editörünün” hiçbir sorumluluğunun olmadığ1, tüm sorumluluğun Sorumlu Yazara ait olduğu ve bu çalışmanın herhangi başka bir akademik yayın ortamına değerlendirme için gönderilmemiş olduğu sorumlu yazar tarafından taahhüt edilmiştir.

\section{Authors' Biodata/ Yazar Bilgileri}

Gökhan KARADİREK, lisans öğrenimini Anadolu Üniversitesi İşletme Fakültesi İşletme alanında almıştır. Yüksek lisans eğitimini Gümüşhane Üniversitesi Sosyal Bilimler Enstitüsü İşletme alanında, doktorasını ise Giresun Üniversitesi Sosyal Bilimler Enstitüsü İşletme alanında tamamlamıştır. Yazar, Giresun Üniversitesi Alucra 
Turan Bulutçu Meslek Yüksekokulu'nda öğretim görevlisi olarak görevine devam etmektedir.

Gökhan Karadirek, Lecturer, $\mathrm{PhD}$, received his bachelor's degree in Business Administration from the Faculty of Business Administration of Anadolu University. He completed his master's degree in the field of Business Administration, Institute of Social Sciences at Gümüşhane University and his doctorate in the field of Business Administration, Institute of Social Sciences at Giresun University. The author currently works as a lecturer at Alucra Turan Bulutçu Vocational Education \& Training School. 